\title{
PERAN PEKERJA SOSIAL DALAM SISTEM USAHA KESEJAHTERAAN SOSIAL DI ERA MILLENNIUM
}

\author{
Oleh: \\ Purwowibowo
}

"It is argued that no-one in a civilized society should be in a position where they cannot afford the basic necessities of life" (sangat memprihatinkan jika seseorang yang hidup di dalam masyarakat beradab (modern), mereka tidak mampu memenuhi kebutuhan dasarnya, Thompson dalam Edi Suharto, 2011: 16)

\begin{abstract}
Abstraks
Tulisan ini merupakan kajian pustaka yang membahas tantangan profesi pekerjaan sosial di Abad 21. Sejak awal perkembangan profesi ini masih dianggap sebelah mata oleh profesi lain, karena tumbuh-kembangnya kalah cepat dengan perkembangan masalah sosial di era modern. Sehingga usaha kesejahteraan sosial yang diselenggarakan seringkali tertinggal dengan SUKS yang sekarang ini telah banyak yang berbasis profit. Agar gap perkembangan profesi ini tidak terjadi, diperlukan revitalisasi profesi pekerjaan sosial, mulai dari dunia pendidikan sampai sistem intervensi yang dilakukan. Teori-teori harus selalu dikembangkan, metode intervensi diperbaharui, dan nilai-nilai modern yang berbasis bisnis harus pula digunakan. Dengan selalu meng-up-date ketiga hal di atas, profesi pekerjaan sosial dapat selalu eksis di tengah sistem SUKS di era millennium.
\end{abstract}

Kata Kunci: Peran Pekerja Sosial, Sistem Usaha Kesejahteraan Sosial, Era Millenium

\begin{abstract}
This paper is a literature review that addresses the challenges of the social work profession in the 21st Century. Since the beginning of the development of the profession is still considered one eye by other professions, because the development of practices and theories of social work less rapidly growth with the increasing of the social problems in the modern era. Thus, the organized social welfare often left behind with business of social welfare systems currently has many profitbased. In order for this professional development gap does not happen, the revitalization of the social work profession, ranging from education to the intervention system. Theories and practices must always be developed, updated methods of intervention, and modern values-based business must also be used. By always to up-date the three items above, the social work profession can always exist on the business of social welfare systems in millennium era.
\end{abstract}

Keywords: Social Worker Role, Business of Social Welfare System, Millenium Era

\section{PENDAHULUAN}

Pekerja sosial profesional terus mendapatkan tempat di tengah kehidupan masyarakat di dekade millenium ini. Pekerja sosial bisa bekerja bersama dengan kelompok klien di rumah singgah, panti-panti atau yayasan sosial, tempat-tempat rehabilitasi, 
menangani korban bencana, perang, pengungsi, dan juga menangani masalah kemiskinan. Dengan demikian dapatlah dikatakan bahwa sebagai pekerja sosial secara nyata dapat berfungsi dalam kehidupan masyarakat. Pekerja sosial menyebar dan berhimpun di dalam ikatan pekerja sosial internasional (International Federation of Social Work/IFSW), yang mempunyai anggota di lingkup regional, nasional, sampai di tingkat lokal. Di Indonesia sendiri ada wadah bagi pekerja sosial ini dengan nama Ikatan Pekerja Sosial Profesional Indonesia (IPSPI). Dengan menggunakan berbagai bahasa dan literatur, baik berupa teori-teori, nilai dan norma, serta pengalaman praktik yang terus mengalami perkembangan, pekerja sosial sosial profesional keberadaannya masih tetap dibutuhkan.

Mereka yang tertarik menjadi pekerja sosial (Social Worker) sebagai pilihan karier atau profesi, merupakan keputusan yang tidak mudah. Karena, bidang pekerjaan yang berkaitan dengan masalah sosial dan kesejahteraan sosial bukan hanya ditangani oleh pekerja sosial, tetapi banyak profesi lain juga berperan. Itulah sebabnya, profesi pekerjaan sosial harus meningkatkan kemampuan profesionalnya. Meskipun telah banyak lulusan dari lembaga pendidikan pekerjaan sosial dan kesejahteraan sosial, namun, gaung pekerja sosial profesional belum didengar dan diperhatikan oleh masyarakat luas. Menurut Laporan Tahunan STKS Bandung (2007), lembaga pendidikan tersebut telah menghasilkan lulusan sebanyak 10627, belum lagi ditambah lulusan dari berbagai lembaga pendidikan lain di Indonesia yang bernaung di Ikatan Pendidikan Pekerjaan Sosial Indonesia (IPPSI), tentu jumlahnya telah lebih banyak. Namun, ditengah-tengah upaya untuk menjadikan profesi pekerjaan sosial sebagai suatu yang profesional dan diakui, masih banyak tantangan yang menghadang. Pekerja sosial yang tidak profesional (nonprofesional/amatir), semi profesional (paraprofesional), juga berkiprah dalam melakukan pekerjaan sosial. Perebutan lahan pekerjaan yang berkaitan dengan masalah sosial dan usaha kesejahteraan sosial oleh berbagai profesi itulah yang akhirnya mengharuskan pekerjaan sosial profesional merevitalisasi kemampuan profesionalnya.

Di dalam MDGs (2000) sejak awal dicanangkan 8 (delapan) program yang berkatian dengan masalah kesejahteraan sosial, yang meliputi: (1) Diakhirnya masalah kemiskinan dan kelaparan; (2) Pendidikan untuk semua; (3) Kesamaan Gender; (4) Kesehatan anak; (5) Kesehatan ibu hamil; (6) Perang melawan HIV/AIDs; (7) Kelestarian lingkungan; dan (8) Kemitraan global. Secara khusus diharapkan pada tahun 2015 semua negara di dunia harus terbebas dari kemiskinan dan kelaparan. Melihat program MDGs tersebut jelas bahwa dibutuhkan peran pekerja sosial untuk merealisasikannya.

Di Indonesia sendiri meskipun dilaporkan (BPS, 2012) menurun jumlah penduduk miskin, tetapi laporan ADB (2011) jumlah orang miskin di Indonesia lebih dari 40 juta. Karena kemiskinan merupakan inti dari masalah sosial, maka masalah ikutan dari kemiskinan juga terus bertambah. Dengan bertambahnya masalah sosial, pekerja sosial dapat berperan aktif di dalam menangani masalah sosial yang terjadi ditengah masyarakat. Agar dapat berperan secara profesional pekerja sosial dituntut untuk melakukan pembenahan diri, mengasah ketrampilan, kemampuan, pengalaman praktik, dan kapasitasnya untuk dapat disebut sebagai pekerja sosial profesional. Menjadi pekerja profesional, bukan hanya tanggung jawab seorang pekerja sosial itu sendiri, melainkan juga melibatkan peran lembaga pendidikan dan asosiasi pekerjaan pekerjaan sosial, yang harus bersama-sama mewujudkan profesi pekerjaan sosial secara profesional. Karena jika tidak membenahi diri, bisa saja pekerja sosial akan terpinggirkan oleh profesi lain, yang mereka telah melakukan pekerjaan secara profesional.

Dengan tantangan yang menghadang seperti diuraikan di atas muncul permasalahan: apakah pekerja sosial profesional bisa memainkan perannya dalam 
menangani masalah sosial di era millennium? Apakah yang harus dilakukan lembaga pendidikan dalam menyiapkan lulusannya dalam menghadapi era millennium? Jika pertanyaan-pertanyaan tersebut tidak mampu dijawab, bisa jadi pekerja sosial profesional hanyalah sosok yang tanpa isi, sehingga tidak bisa berperan aktif dan hanya dapat bekerja dalam setting terbatas, bahkan bisa terpinggirkan oleh profesi lain. Oleh karena itu, diperlukan langkah kongkrit agar pekerja sosial dapat berperan dan menjadi bagian penting dalam usaha kesejahteraan sosial modern.

\section{PEMBAHASAN}

\subsection{Sistem Usaha Kesejahteraan Sosial}

Usaha kesejahteraan sosial sesungguhnya merupakan pengembangan lembaga sosial tradisional untuk menyediakan layanan berbagai kondisi dari ketergantungan kelompok rentan dan disabel ditengah masyarakat. Dalam konteks yang lebih luas (makro) usaha kesejahteraan sosial demikian disebut dengan konsep negara kesejahteraan (welfare state). Di dalam negara kesejahteraan masalah sosial yang terjadi bukan hanya tanggung jawab individu, kelompok, dan masyarakat, tetapi menjadi tanggung jawab bersama, yakni merupakan tanggung jawab negara. Secara teoritis, Edi Suharto (2006), menjelaskan bahwa negara kesejahteraan harus berusaha untuk melindungi seluruh warganya pada kondisi sebaik mungkin. Di dalam tataran praktis, negara kesejahteraan dapat ditelusuri, tidak dengan kondisi yang ideal, yakni negara bisa menyediakan layanan, sejauh intervensi negara dapat diterima dan syah, dan peran negara sesungguhnya sangat kompleks, yaitu mengawasi ketentuan atau aturan kesejahteraan di seluruh lapisan masyarakat, menentukan peraturan, memberikan mandat, membangkitkan semangat, dan membuka saluran alternatif bagi ketentuan kesejahteraan sosial.
Asal mula layanan sosial (social services) digunakan dalam konsep sangat terbatas. Seperti layanan medis atau kesehatan, jaminan sosial, perumahan, pendidikan, dan pekerjaan sosial. Titmuss dalam Phillips (2002) menjelaskan bahwa pendekatan demikian layanan sosial sangat terbatas, dan mengarah ketidak konsistenan di dalam membahas mengenai kesejahteraan. Dengan menggunakan dua contoh, tentang subsidi pemerintah kepada petani penyewa disebut juga sebagai pelayanan sosial, tetapi peraturan mengenai subsidi, dan pengendalian ekonomi dari industri untuk peningkatan kapasitas tenaga kerja tidak disebut sebagai pemberian layanan sosial. Menurutnya penggunaan konsep demikian adalah kesewenang-wenangan dan bahkan suatu konsep yang menyesatkan.

Layanan sosial dapat dibedakan paling tidak dengan apa yang mereka lakukan dan dari mana mereka lakukan. Pertama, layanan sosial harus merupakan aktivitas yang terorganisasi. Karena banyak usaha kesejahteraan sosial dilakukan secara informal: seperti layanan oleh keluarga, layanan sukarela baik individu maupun masyarakat yang pada umumnya dilandasi dengan organisasi amal. Kedua, layanan sosial yang didistribusikan kembali (dalam bentuk asuransi sosial), orang yang membayar premi tertentu akan memperoleh keuntungan berupa jaminan sosial.

Banyak kegiatan terorganisir yang berkaitan dengan layanan sosial dan pendistribusian kembali, tetapi tidak diklasifikasikan ke dalam pelayanan sosial. Pada umumnya menunjuk kepada pelayanan publik. Misalnya polisi, angkatan bersenjata, pembersih jalan, tukang parkir, dan banyak lagi yang berkaitan dengan pelayanan publik. Namun, layanan kolektif yang menguntungkan semua masyarakat dapat dikatakan sebagai pelayanan sosial. Misalnya, pelayanan kesehatan, pendidikan, jaring pengaman sosial (social safety net), dan banyak lagi bentuk-bentuk layanan sosial yang masuk ke dalam sistem usaha kesejahteraan sosial. 
Pengertian Sistem Usaha Kesejahteraan Sosial" atau "Business of Social Welfare" dari Perserikatan BangsaBangsa (PBB) dalam United Report (1968: 40-41), adalah:

"an organized activity that aims at helping towards a mutual adjustment of individuals and their social environment. This objective is achieved through the use of techniques and methods which are designed to enable individuals, groups, and communities to meet their need and solve their problems of adjusment to a changing pattern of society, and through cooperative action to improve economic and social condition"

Dengan melihat batasan yang dibuat PBB ini tampak bahwa penekanannya pada suatu kegiatan atau aktivitas yang terorganisasi. Batasan tersebut telah mementingkan aturan-aturan permainan, seperti ditunjukkan oleh kalimat "through the use of technique and methods". Barangkali pengertian "technique" dan "methods" di sini belum bersangkut paut dengan metodologi dalam ilmu pengetahuan. Namun, penting untuk dicatat bahwa PBB telah melihat kelemahan-kelemahan yang dilakukan oleh berbagai institusi, yang usaha-usaha untuk meningkatkan "welfare" tidak melalui teknik dan metode yang teratur, tetapi bersifat sporadis dan bahkan tidak berdasarkan praktik profesional.

Sistem Usaha Kesejahteraan Sosial menekankan suatu sistem hukum, program, dan layanan untuk memperkuat dan menjamin terpenuhinya kebutuhan dasar sehingga tercapai kesejahteraan penduduk dan berfungsinya keteraturan sosial (Wickenden, 1965 p. vii; Friedlander, 1974: 3; Crampsto dan Caisar, 1970; Romanyshyn, 1971). Dengan demikian dapat dikatakan bahwa usaha kesejahteraan sosial merupakan suatu sistem yang meliputi pendekatan multiaspek terhadap permasalahan sosial dan ekonomi, dan juga mencerminkan nilai-nilai kemanusiaan. Turner (1974) dan Midgley
(1995) menyebutnya dengan pembangunan sosial, karena tidak hanya untuk memenuhi kebutuhan ekonomi saja, tetapi menyelaraskan antara kebutuhan ekonomi dengan kebutuhan sosial.

Hampir semua manusia yang hidup di dunia ini selalu menghadapi masalah, baik masalah kecil, menengah, atau besar. Masalah yang muncul di berbagai kehidupan manusia itu bisa berupa kematian anggota keluarga, kemiskinan, kebodohan, butahuruf, kesehatan, penghasilan yang rendah, kurangnya kesempatan kerja, pemutusan hubungan kerja, dan lain sebagainya. Dalam kehidupan masyarakat, keluarga merupakan unit terkecil dari masyarakat, oleh sebab itu peran keluarga dalam memecahkan masalah yang dihadapi oleh anggota keluarga tersebut sangatlah penting. Jika suatu keluarga tidak mampu untuk menyelesaikan masalah yang terjadi, maka peran lembaga-lembaga sosial sangat diperlukan, terutama dalam bentuk sistem usaha kesejahteraan sosial, baik yang diselenggarakan oleh lembaga pemerintah maupun swasta. Dengan berkembangnya kehidupan masyarakat dan semakin modern, justru ketergantungan anggota masyarakat terhadap lembaga-lembaga sosial yang ada semakin tinggi.

Oleh karena itu, suatu sistem usaha kesejahteraan sosial sangat dibutuhkan kehadirannya, karena dengan sistem ini, suatu profesi pekerjaan sosial mempunyai kedudukan yang penting untuk melakukan berbagai bentuk intervensi sosial yang dibutuhkan guna mewujudkan kesejahteraan sosial di masyarakat.

\subsection{Peran Pekerja Sosial dalam SUKS}

Pekerjaan sosial merupakan suatu profesi yang utama dalam mewujudkan kesejahteraan sosial bagi seluruh anggota masyarakat. Profesi ini berfungsi untuk melakukan analisis kebijakan dan perencanaan kesejahteraan sosial, memperbaiki dan meningkatkan kehidupan sosial, mengembangkan sumber daya 
manusia, melakukan penyembuhan sosial, rehabilitasi sosial, mencegah timbulnya masalah sosial, memberdayakan kelompok rentan, dan lain sebagainya.

Selain hal tersebut profesi pekerjaan sosial juga befungsi mencegah (preventif) terhadap timbulnya masalah sosial dari interaksi antar anggota masyarakat, mengembangkan dan memelihara serta memperkuat sistem usaha kesejahteraan sosial, menjamin terpenuhinya kebutuhan dasar manusia, meningkatkan keberfungsian sosial masyarakat, mengenali dan menumbuhkembangkan potensi anggota masyarakat, menjaga ketertiban sosial, dan berbagai kegiatan lainnya yang berkaitan dengan kesejahteraan sosial. Dengan kata lain, bahwa pekerjaan sosial berupaya untuk mendayagunakan semua potensi yang ada guna mencapai kesejahteraan hidup masyarakat.

Secara khusus tujuan pekerjaan sosial adalah untuk meningkatkan keberfungsian sosial anggota masyarakat yang mengalami masalah, sehingga mereka mampu mengatasi masalahnya sendiri (selfhelp services), membantu adaptasi sosial, dan melakukan perubahan sosial di lingkungannya agar sumber daya yang ada dapat bermanfaat bagi kehidupan masyarakat. Atas dasar tersebut Hepworth et al. (1993) menjelaskan ruang lingkup pekerjaan sosial meliputi: (1) memberikan layanan terhadap masyarakat (public assistence); (2) jaminan sosial (social insurance); (3) penanganan keluarga (family service); (4) penanganan kesehatan dan medis (health and medical service); (5) penanganan masalah anak (child welfare service); (6) penanganan kesehatan mental (mental health service); (7) penanganan koreksional (corectional service); (8) penanganan remaja (youth service); (9) penanganan orang lanjut usia (aging service); (10) pekerjaan sosial industri (industrial social work); (11) memberikan layanan perumahan atau pemukiman (reseltlement service); dan (12) penanganan masalah sosial internasional (international social service).
Pekerjaan sosial merupakan profesi pemberian bantuan yang secara historis merupakan tanggapan untuk memecahkan masalah dari meluaskan masalah sosial di tengah masyarakat, yang individu, keluarga, dan masyarkat tidak mampu menyelesaikan masalahnya sendiri. Sampai sekarang ini, profesi ini telah memiliki kode etik tersendiri di dalam melakukan pekerjaan sosial guna memenuhi kebutuhan dasar manusia yang berasal dari nilai-nilai kemanusian seperti: (1) service; (2) social justice; (3) dignity and worth of the person; (4) importance of human relationship; (5) integrity; and (6) competence (NASW, 1999). Oleh karena itu, pekerja sosial bisa disebut sebagai pekerja profesional jika memenuhi persyaratan di atas..

Pekerja sosial memberikan layanan kepada semua kelompok umur, mulai dari anak yang baru lahir sampai orang tua renta. Mereka membantu semua orang dengan pengalamannya untuk mengatasi masalah sosial yang dihadapinya, seperti misalnya, gelandangan, masalah rumah tangga, kekerasan terhadap anak, stres dalam pekerjaan, dan lain sebagainya. Namun, sesungguhnya ruang lingkup dari pekerjaan sosial lebih luas dari apa yang telah diberikan terhadap individu, keluarga, atau mungkin kelompok kecil dan masyarakat.

Seringkali tidak terlihat, tetapi ternyata penting bahwa misi dari pekerjaan sosial sampai kepada pembelaan (advocacy) keadilan sosial bagi orang-orang yang suara hatinya tidak terdengar oleh penguasa, misalnya orang miskin, anak-anak yang kurang beruntung atau mengalami kekerasan, dan orang tertindas. Pekerjaan sosial juga bekerja sebagai administrator di lembaga sosial dan pemberian pertimbangan untuk menjamin kualitas pelayanan terhadap program dan layanan yang diberikan. Selain itu, pekerja sosial dapat bekerja sebagai analis kebijakan, pelobi politik, pembela, pendidik, dan juga peneliti sosial.

Dengan terus berkembangnya ilmu dan pengetahuan mengenai kesejahteraan sosial dan pekerjaan sosial, maka pekerja 
sosial harus berupaya untuk meningkatkan ilmu pengetahuan, yang berupa teori dan praktik, sehingga dapat melakukan pembelaan terhadap masalah keadilan sosial dan perubahan sosial bagi klien. Pekerja sosial juga menggunakan etika dan budaya (sesuai dengan kode etik pekerjaan sosial) yang berbeda-beda untuk mengurangi diskriminasi, kemiskinan, dan berbagai bentuk ketidak-adilan lainnya. Kesemuanya itu merupakan bentuk pelayanan langsung (direct services) terhadap kepentingan masyarakat. Menurut Edi Suharto (2010: 21) misi yang diemban oleh pekerja sosial di dalam kerangka kesejahteraan sosial adalah, (1) meningkatkan kualitas hidup masyarakat yang tidak memiliki kemampuan dalam menjangkau dan memenuhi kebutuhan dasarnya sesuai dengan harkat dan martabat kemanusiaan; (2) memperkuat kepedulian masyarakat dalam pembangunan kesejahteraan sosial sejalan dengan prinsip masyarakat peduli (carying society) dan kesetiakawanan sosial; (3) memantapkan dan mengembangkan keberdayaan dan ketahanan sosial masyarakat melalui sistem perlindungan sosial yang inklusif, partisipatif, dan berkeadilan sosial.

\subsection{Sistem Usaha Kesejahteraan Sosial Modern}

Globalisasi berjalan beriringan dengan hadirnya era milenium baru, yang pada era ini perubahan sosial terjadi dengan sangat cepat dan bersifat massif, merambah semua sisi kehidupan manusia di manapun manusia berada. Globalisasi sering dikonotasikan dengan proses internasionalisasi perekonomian yang ditandai dengan perdagangan bebas disertai penggunaan teknologi canggih. Lahirnya dilandasi dengan politik dan ideologi neo-liberalisme, yang intinya menekankan pentingnya kebebasan, khususnya kebebasan ekonomi dari campur tangan negara. Di sini negara dipandang sebagai penghambat mekanisme pasar dan karenanya menganggu pertumbuhan ekonomi. Dengan kata lain neo-liberalisme sangat anti terhadap "welfare state dan development state" (Edi Suharto, 2010: 239).

Dengan pengaruh globalisasi itu konsep kesejahteraan sosial dan pekerjaan sosial berkembang pula, diikuti dengan bermunculannya sistem usaha kesejahteraan sosial yang sangat beraneka ragam dan bahkan dilandasi oleh kepentingan ekonomi (business). Untuk itu sangatlah penting bagi semua pekerja sosial dapat memahami ruang lingkup, sejarah perkembangan (asal-usul), dan tujuan sistem usaha kesejahteraan sosial secara luas, kemudian memahami pula peran yang dimainkan oleh pekerja sosial dan lembaga-lembaga sosial di dalam sistem usaha kesejahteraan sosial modern. Kesejahteraan pada awal mulanya hanya menunjuk pada orang-orang miskin yang menerima bantuan dari program yang diselenggarakan oleh pemerintah maupun swasta melalui lembaga sosialnya, seperti layanan masyarakat dan pemberian bantuan makanan, layanan kesehatan, layanan anak, layanan orang tua, layanan orang disabel, dan layanan lainnya. Kemudian berkembang dan saat ini konsep kesejahteraan menjadi sangat luas dan mencakup kegiatan lain dari program kesejahteraan yang ada di tengah masyarakat.

Berkembangnya konsep kesejahteraan tidak terlepas dari perkembangan peradaban masyarakat yang terus maju dan mendunia. Menurut Titmuss dalam Phillips (2002), yang dikenal sebagai ahli ekonomi Inggris, menyarankan kepada semua orang bahwa kesejahteraan tidak hanya berhubungan dengan pemberian bantuan kepada orang miskin saja, tetapi sekarang semua orang bisa mendapatkan keuntungan dari penyelenggaraan sistem usaha kesejahteraan sosial. Sekarang kenyataannya di AS, Inggris, dan negara maju lainnya telah ada programprogram besar, tidak hanya diperuntukkan bagi orang miskin, tetapi bagi semua orang yang rentan, pekerja rendahan, pengusaha kecil, petani, dan kelompok-kelompok lainnya. Semakin luasnya program dan usaha kesejahteraan sosial, maka sangat berguna bagi pekerja sosial untuk selalu pula memahami semakin luasnya konsep 
kesejahteraan. Dengan demikian pekerja sosial menjadi lebih realitis memahami perannya di dalam sistem usaha kesejahteraan sosial, baik yang dilakukan oleh pemerintah, swasta, dan masyarakat di dalam menyediakan layanan bagi semua orang.

Selanjutnya Titmuss dalam Phillips (2002), menyatakan bahwa ada 3 bentuk kesejahteraan di masyarakat modern saat ini yakni: (1) kesejahteraan keuangan (fiscal welfare); (2) kesejahteraan pekerjaan (occupational welfare); dan (3) kesejahteraan sosial (social welfare).

Kesejahteraan Keuangan (Fiscal Welfare) adalah sebuah produk dari hukum pajak, yang menyediakan keuntungan ekonomi bagi orang-orang melalui sistem pajak yang dirancang. Kesejahteraan keuangan ini diberikan dari hasil pajak pemerintah federal, negara, atau pemerintah lokal. Misalnya, pendapatan pajak pemerintah didapatkan dari pengenaan pajak progresif, agar supaya orang-orang yang mempunyai pendapatan tinggi membayar lebih besar pajaknya daripada orang miskin. Dalam bahasa Indonesia disebut sebagai subsidi silang. Tujuan dari pajak progresif ini adalah untuk mendistribusikan pengenaan pajak agar lebih adil dan merata. Sekarang telah banyak orang yang diuntungkan dari pengenaan pajak progresif ini. Dengan adanya penambahan beban pajak bagi orang kaya, maka pendapatan pajak akan dapat dipergunakan untuk membiayai usaha kesejahteraan sosial yang lebih luas.

Kesejahteraan fiskal juga sudah digunakan di dalam kelompok sosial ekonomi kecil. Misalnya pemberian kredit bagi orang yang berpenghasilan rendah, hal ini di AS disebut dengan program "anti kemiskinan" dan di Indonesia disebut dengan program "pengentasan kemiskinan". Dapat juga digunakan untuk program penangan anak bagi keluarga yang berpenghasilan di bawah garis kemiskinan.

Kesejahteraan kerja (Occupational Welfare) adalah suatu program kesejahteraan yang dirancang untuk memberikan bantuan kepada para pekerja baik yang bekerja di perusahaan maupun anggota keluarga yang bekerja di keluarganya. Bentuk kesejahteraan kerja ini sudah termasuk asuransi kesehatan bagi para buruh dan juga pekerja keluarga, pemberian bantuan pensiun, membayar ongkos berobat di rumah sakit, biaya rekreasi, dan lain sebagainya. Kesejahteraan kerja sangat luas cakupannya, karena mencakup penanganan anak buruh, anggota kelompok buruh atau pekerja, dan bisa juga memberi bantuan untuk merenovasi rumah, dan lainnya. Sekarang banyak perusahaan besar telah menyelenggarakan kesejahteraan kerja ini, termasuk memberikan layanan konseling bagi buruh dan keluargannya secara gratis.

Kesejahteraan sosial (Social Welfare) adalah suatu kegiatan yang meliputi pelayanan terhadap orang miskin dan juga kegiatan pemberian bantuan kepada semua kelompok yang berpenghasilan rendah. Seperti halnya kesejahteraan sosial yang diberikan kepada keluarga dan pemberikan bantuan kepada orang miskin di daerah perkotaan. Kegiatan lain yang termasuk usaha kesejahteraan sosial ini adalah: (1) pemberian bantuan kepada pengangguran dan pekerja miskin yang penghasilannya sangat rendah dan hanya cukup untuk memenuhi kebutuhan minimum dasarnya, sehingga mereka harus dijamin penghasilannya, kesehatannya, dan ada program pemberian pangan kepadanya; (2) keluarga yang tidak mampu di dalam menyewa rumah yang mahal, mereka harus ditampung di tempat penampungan atau rumah singgah; (3) keluarga buruh kecil yang tidak mampu merawat anak-anak mereka, anak-anak harus dibiayai oleh program pemberdayaan anak, ada program sekolah lanjut, dan juga program tempat tinggal di musim panas; (4) Rehabilitasi terhadap para pecandu obat dibantu pembiyaannya. 


\subsection{Peran Pekerja Sosial di dalam SUKS Modern}

Program layanan sosial di masyarakat modern sekarang ini dapat dibagi menjadi dua kategori, yang masing-masing didukung dan ditanggung pembiayaannya oleh kebijakan dan keuangan negara dan swasta. Dua sektor itu meliputi, (1) sektor publik, termasuk semua lembaga dan organisasi di bawah tanggung jawab negara, pemerintah daerah, dan pusat; (2) sektor swasta, termasuk lembaga amal, lembaga nir-laba, dan juga lembaga profit lainnya.

\subsubsection{SUKS dalam sektor publik yang dilakukan oleh negara}

Kesejahteran sosial dan pelayanan sosial dibentuk oleh negara melalui undangundang dan peraturan, baik pemerintah pusat, federal, dan pemerintah daerah. Misalnya perpustakaan umum, yang diperuntukkan bagi semua orang pengeloaan dan anggarannya di tanggung oleh negara melalui pengenaan pajak atau ristribusi yang diatur dengan UU dan Peraturan.

Penting bagi pekerja sosial untuk memahami kesejahteraan sosial sektor publik, karena sangat berguna untuk membedakan dua organisasi yang bergerak di tengah masyarakat, yakni model institusional (institutional model) atau disebut dengan model umum (universal model), dan model residual disebut sebagai "selective model".

\section{1) Model Institusional}

Model institutional adalah suatu model yang dibentuk atas keyakinan bahwa manusia mempunyai hak untuk terpenuhinya kebutuhan dasarnya, dan pemerintah mempunyai "kuajiban" untuk menyediakan berbagai kebutuhan tersebut. Atas dasar komitmen tentang "keadilan sosial" seorang individu mempunyai hak terpenuhinya kebutuhan yang mereka butuhkan tanpa memperhatikan pendapatan dan stigma buruknya. Walaupun banyak orang telah menerapkan komitmen keadilan sosial ini berdasarkan kondisi yang ada dan telah diterima oleh seluruh masyarakat, seperti terhadap orang tua, pengangguran, dan jaminan atau asuransi kesehatan, tetapi orang belum mendapatkan layanan yang memadai masih banyak kita jumpai. Pendidikan bagi semua orang dan asuransi pengangguran sebagai contoh model institusional ini dan juga disebut dengan negara kesejahteraan atau welfare state (Edi Suharto 2006; Spicker, 1993, Fukuyama, 2005),

Di beberapa negara Eropa seperti, Inggris, Swedia, dan Swiss, telah menyatakan sebagai negara dengan konsep negara sejahtera. Walaupun negara sejahtera menghadapi masalah keuangan yang bisa memangkas anggaran negaranya untuk kegiatan kesejahteraan sosial, di negaranegara tersebut pemerintahnya merasa yakin bahwa negara bertanggung jawab terhadap kesehatan bagi semua warganya, melakukan perlindungan sosial terhadap anak-anak di dalam keluarga tertentu, memberi asuransi pengangguran, keluarga 'single parent' ditanggung oleh negara.

\section{2) Model Residual}

Model ini didasarkan atas keyakinan bahwa individu dan anggota keluarganya bertanggung jawab terhadap pemenuhan kebutuhan dasarnya sendiri. Keyakinan tersebut dilandasi atas pemikiran bahwa: (1) kesempatan kerja sangat banyak tersedia bagi banyak orang; (2) semua orang dianggap mampu mendapatkan gaji untuk memenuhi kebutuhan sendiri dan keluarganya; (3) jika ada orang atau keluarga yang tidak mampu memenuhi kebutuhannya sendiri dan keluarganya, hal itu merupakan kesalahan atau kegagalan mereka masing-masing.

Model ini masyarakat menyediakan usaha kesejahteraan sosial bagi orang-orang yang betul-betul tidak mampu dan sangat membutuhkan pertolongan. Hal ini disebut dengan "jaring pengaman sosial" (social safety net). Sekalipun model institusional dilandasi atas komitmen tentang keadilan sosial, pada model residual dilandasi atas belas kasihan (charity), bentuknya bisa 
berupa perawatan medis, bantuan makanan, dan program perumahan. Program semacam ini diperuntukkan bagi orang-orang yang secara khusus dikatakan sebagai suatu kondisi "darurat" yang kehidupannya di bawah garis kemiskinan menurut peraturan negara yang bersangkutan.

\subsubsection{SUKS yang dilakukan oleh lembaga di sektor swasta}

Sistem usaha kesejahteraan sosial yang dilakukan oleh sektor swasta dibagi menjadi dua tipe yakni: (1) organisasi amal yang nir-laba; (2) organisasi swasta yang berorentasi keuntungan, yang sekarang ini berkembang sangat pesat berkaitan dengan lajunya pembangunan, modernisasi, industrialisasi, dan globalisasi.

\section{1) Organisasi nir-laba yang bersifat amal}

Banyak orang mengira bahwa organisasi dan lembaga yang berdiri di masyarakat sesungguhnya dibentuk atas dasar sukarela atau amal, karena pekerja sosial di jaman dulu dalam melaksanakan tugasnya tidak mendapatkan imbalan atau gaji tertentu. Hal ini benar adanya sewaktu organisasi semacam itu didirikan. Berbeda saat ini, karena pekerja sosial dalam bekerja mendapatkan gaji tertentu atas apa yang telah dikerjakan, maka sekarang ini banyak lembaga nir-laba mendapatkan bantuan dana internasional, misalnya kita semua telah mengenalnya organisasi nir-laba yang terus berkembang pesat yakni "palang merah internasional" atau PMI.

Sekarang organisasi nir-laba telah menggabungkan pendanaanya baik dari masyarakat maupun dari pemerintah, dan mengadakan kontrak kerjasama dengan organisasi amal dan kemudian mempercayakannya pelayanan sosial bersama-sama dengan sektor publik, misalnya lembaga penanganan anak, sektor swasta dalam hal ini menjadi bagian dari sektor publik. Disebut sebagai organisasi nir-laba yang berorentasi amal, karena lembaga tersebut tidak dimiliki oleh seseorang baik individu maupun penyandang dana (stakeholders). Organisasi amal setelah membayar semua pembiayaan, termasuk gaji para pekerja sosialnya, keuntungan menjadi milik lembaga atau yayasan tersebut. Organisasi nir-laba juga tidak dibebani dengan berbagai macam pajak, misalnya pajak pendapatan dan pajak penjualan, dan pajak lainnya.

Nilai dan tanggung jawab yang diemban oleh organisasi nir-laba adalah "nilai kemanusiaan" . Jadi amat penting bagi pekerja sosial untuk memahami dan lebih mengenal nilai, tujuan, dan cara kerja, standar, dan tanggung jawab dari masingmasing organisasi nir-laba, sebelum pekerja sosial bersama lembaga ini terutama berkaitan dengan klien yang ditangani. Lembaga amal yang nir-laba, dapat diidentifikasi sebagai suatu lembaga memberikan layanan secara "sektarian" yang kegiatannya berhubungan dengan agama tertentu, dan "non-sektarian" yang lebih sekuler.

\section{2) Lembaga sosial swasta yang berorientasi Profit}

Di jaman sekarang ada kecenderungan munculnya privatisasi atau swastanisasi dari banyak pelayanan sosial kepada masyarakat. Privatisasi lembaga pelayanan sosial di Amerika semakin meluas beberapa dekade terakhir ini (Devonne, 1998). Sebagian berbau bisnis, organisasi demikian pemiliknya bisa individu atau beberapa orang penyandang dana. Lembaga semacam itu berusaha sekuat mungkin untuk memperoleh keuntungan dari organisasi yang didirikan, karena orientasinya memang ingin mendapatkan keuntungan bagi pemiliknya dan penyandang dananya.

Meskipun beberapa tahun lalu pekerja sosial banyak yang bekerja di organisasi swasta yang dilandasi amal, sekarang ini banyak pekerja sosial yang terlibat di dalam organisasi swasta yang berorientasi keuntungan ini. Hal ini menjadikan lingkup pekerjaan sosial semakin luas dari tradisional berkembang menjadi modern, mulai 
organisasi amal kemudian menjadi organisasi yang mencari keuntungan, bukan hanya lingkup lokal, nasional, bahkan sudah merambah di lingkup internasional (Midgley, 1997; Chang-Muy 2009).

Banyak bermunculan lembaga sosial swasta semacam itu, misalnya (1) dalam kesejahteraan anak, dari hari ke hari tempat penitipan anak sekarang berorientasi bisnis, biasanya muncul di kawasan industri maupun perkotaan; (2) dalam rekreasi, berhubungan dengan program rekreasi diperkenalkan pada masyarakat kota yang dikelola profesional; (3) rehabilitasi kecanduan obat terlarang, banyak program rehabilitasi bermunculan dengan maksud mendapatkan keuntungan ekonomi; (4) penanganan remaja, banyak berhubungan dengan perawatan rumah, perluasan layanan, dan pendirian fasilitas umum di perumahan; (5) pelayanan kesehatan, kesehatan jiwa, dilakukan oleh lembaga swasta dan dikelola dengan profesional; (6) pelayanan koreksi, pelayanan terhadap narapidana di rumah tahanan yang juga berorientasi bisnis.

Tren seperti di atas akan terus berkembang dan bermunculan di tengah kehidupan masyarakat, dengan harapan semakin banyak bermunculan semakin banyak klien tertolong dan ditangani dengan baik. Di masa mendatang pekerja sosial akan lebih luas bidang cakupannya dan wilayah kerjanya. Meskipun organisasi swasta ada perbedaan dalam memberikan layanan, tetapi setidaknya pelayanan standar masih dapat dilakukan dengan disertai tanggung jawab dan etika pekerjaan sosial. Memang sering terjadi konflik kepentingan di dalam organisasi swasta dalam memberikan layanan kepada masyarakat antara orientasi bisnis dengan memberikan layanan sebagai tugas utamanya.

\subsection{Revitalisasi Pekerja Sosial Profesional}

Semua profesi mempunyai standar tertentu, demikian pula profesi pekerjaan sosial. Pekerja sosial harus menguasai ilmu pengetahuan,

ketrampilan,

yang memungkinkan suatu profesi melakukan kegiatan profesionalnya, serta etika dan nilainilai yang dapat dipraktikan dalam melakukan kegiatannya. Kita mengharap semua pekerja sosial profesional dapat mencapai kemampuan standar. Standarisasi dan profesionalisasi tersebut telah ada regulasinya sendiri di dalam Asosiasi Nasional Pekerja Sosial Profesional nasional, regional, maupun di tingkat internasional. Bahkan Chang-Muy (2009), perlu pengetahuan mengenai multikultural untuk bisa bekerja di level internasional.

Agar bisa bekerja secara profesional menghadapi sistem usaha kesejahteraan yang semakin kompleks di masyarakat modern, seorang pekerja harus dibekali pendidikan yang profesional pula. Materi pendidikannya mencakup seperangkat ilmu pengetahuan kesejahteraan sosial (A body of knowledge of social welfare), kemudian ketrampilan yang cukup (Skills), dan nilai-nilai pekerjaan sosial (Values /social work code of ethics). Sheppard (2006) menambahkan bahwa pekerjaan sosial di era post-modern harus juga mengalami perkembangan dan perubahan, baik teori maupun praktiknya, karena nilai-nilai yang berlaku di era postmo jelas berbeda dengan era sebelumnya.

Seperangkat ilmu pengetahuan yang harus dimiliki oleh pekerja sosial tersebut sesungguhnya merupakan pengetahuan interdisiplin, yang merupakan dasar dari ilmu pekerjaan sosial. Agar pekerja sosial sukses di dalam melakukan pekerjaan sosialnya dia harus mampu memahami manusia dalam masyarakat dengan segala aspeknya.

Pekerja sosial profesional haruslah memperbaharui berbagai disiplin ilmu untuk melakukan pekerjaan sosialnya, seperti ilmu sosiologi, psikologi, biologi, ekonomi, dan ilmu politik yang juga terus mengalami perkembangan. Selain itu juga ilmu sejarah, etika dan ilmu budaya, kajian gender, antropologi pedesaan dan perkotaan, antropologi kesehatan, dan ilmu humaniora yang disebut dengan "Liberal arts perspective". Pekerja sosial dalam melakukan 
pekerjaannya juga menggunakan ilmu biologi, psikologi, dan sosiologi untuk memahami klien yang biasanya disebut dengan "biopsychological perspective"

Kunci dari ketrampilan pekerja sosial adalah hubungan pekerja sosial dengan klien. Pekerja sosial merupakan profesi yang unik karena hubungan antara klien dan pekerja sosial merupakan alat utama dari pelayanan yang dilakukan. Pekerja sosial dalam memberikan layanannya tidak diberi alat khusus atau perangkat nyata, sebagaimana profesi pelayanan lainnya. Pekerja sosial tidak menggunakan alat pengontrol tekanan darah dan juga tidak menulis resep, tetapi pekerja sosial menggunakan ketrampilan yang dimilikinya untuk membangun hubungan profesional dengan klien. Dengan ketrampilannya itu pekerja sosial bisa memberikan layanan, mengidentifikasi, membangun kekuatan klien dan masyarakat.

Dengan luasnya masalah di masyarakat modern, seperti misalnya perbedaan gaya hidup, nilai, ras, suku, budaya, identitas agama, memaksa pekerja sosial untuk selalu tanggap dan selalu belajar dan memahami apa yang terjadi di masyarakat. Dengan demikian, pekerja sosial memerlukan kemampuan (skills) untuk bisa menyadarkan dan mendorong semangat dan kemampuan klien agar pekerja sosial dapat memberikan layanan yang sesuai dengan tujuannya. Hal ini disebut dengan "strengths perspective".

Nilai-nilai dasar pekerjaan sosial sesungguhnya penekannya pada nilai-nilai klien itu sendiri. Dalam melakukan praktik pekerjaan sosial, pekerja sosial harus memperhatikan keunikan dari masing-masing individu, karena individu dipengaruhi nilainilai sosial-budaya yang ada di lingkungannya dan juga keinginannya yang biasanya disebut dengan "client self-determination". Selain itu pekerja sosial sendiri harus mengembangkan "self-awareness", yakni pekerja sosial harus mampu memisahkan kepentingan dirinya dengan kepentingan profesinya. Dengan memisahkan kepentingan dirinya, maka pekerja sosial akan lebih berhasil di dalam memberikan layanannya kepada klien.

Agar bisa bekerja dengan sempurna, pekerja sosial profesional baik yang bergelar sarjana, master, dan doktor, maka diperlukan tambahan ilmu pengetahuan mengenai: (1) selalu meningkatkan kesadaran diri bahwa masalah sosial terus berkembang dan pekerja sosial harus menambah (up-date) pengetahuan yang dimilikinya; (2) meningkatkan kemampuan berkomunikasi dan ketrampilan, hal ini disebut dengan softskill; (3) meningkatkan ketrampilan dalam melakukan asessmen dan perubahan organisasi; (4) lebih memahami dampak perkembangan politik dan ekonomi terhadap masyarakat dan individu; (5) meningkatkan ketrampilan di dalam praktek pekerjaan sosial dan perubahan sosial; (6) meningkatkan ketrampilan melakukan penelitian sosial.

Jika pekerja sosial telah mempersiapkan diri dengan bekal yang cukup, yakni ilmu pengetahuan, ketrampilan, dan nilai-nilai atau etika sesuai perkembangan jaman, maka pekerja sosial telah siap untuk melaksanakan tugasnya di bidang usaha kesejahteraan sosial modern. Fungsi lainnya pekerja sosial adalah menganalisis kebijakan sosial (social policy) yang mungkin dapat mengurangi masalah secara individual dan sosial di suatu lingkungan tertentu, atau melindungi dampak-dampak kerusakan lingkungan sosial dan lingkungan alam yang potensial, merancang situasi kritis seperti program pemberian makanan yang bisa mengatasi kelaparan, dan masalah pengangguran atau orang yang sangat rendah penghasilannya.

Bahkan O'Brien dan Sue Penna (1998) menyarankan di era millennium dan liberalisasi ekonomi, maka pekerja sosial harus berorientasi kepada market, baik teorinya, nilai, dan metode, harus dilakukan perombakan guna menyesuaikan dengan kebutuhan pasar, karena memang pasar yang menentukan dan bukan pekerja sosial. 


\section{KESIMPULAN}

Meskipun masih banyak kontradiksi pemahaman sistem usaha kesejahteraan sosial di masyarakat, yang awalnya mendapat stigma negatif, yakni hanya memberikan bantuan kepada orang miskin saja dan banyak dilandasi dengan amal dan belas kasihan, sekarang ini banyak bermunculan lembaga kesejahteraan sosial yang berorientasi bisnis atau mencari keuntungan. Dengan berkembangnya usaha kesejahteraan sosial di masyarakat industri maka stigma kesejahteraan sosial yang dulunya negatif semakin terkikis, dan menjadi semakin meluas serta mendapatkan tempat di masyarakat. Dengan membenahi diri, selalu meng-up-date pengetahuan, ketrampilan, nilai yang berkembang di kehidupan masyarakat modern, kita semua yakin "pekerja sosial profesional" terus dibutuhkan keberadaan dan kehadirannya di tengah masyarakat modern.

\section{Daftar Bacaan}

1. Asian Development Bank (ADB) 2011. Data Kemiskinan Indonesia.

2. Biro Pusat Statistik, 2012. Penurunan Jumlah Orang Miskin di Indonesia.

3. Chang-Muy, Fernando JD and Eline P. Congress, DSW (Edt). 2009. Social Work With Immigrants and Refugees. Legal Issues, Clinical Skills and Advocasy. New York, Springer Publishing Company.

4. Demone, Jr., H.W. "The Political Future of Privatization" in $\mathrm{M}$. Gibelman 1998. (Eds) The Privatization of Human Services. New York: Springer.

5. Friedlander, Walter, A. and Apte, Rober, Z., 1974. Introduction to Social Welfare, Prentice Hall. Inc. New Jersey.

6. Hepworth, D.H. et al (1993) Direct Social Work Practice Theory and Skill. Wardsworth, Inc. Arizona-USA.

7. Midgley,James. 1995 Soscial Development : The Development
Perspective in Social Welfare, Sage Publication. London.

8. Welfare in Global Context. USA. Sage Publication.

9. O'Brien, Martin and Sue Penna, 1998 Theorising Welfare, Enlightenment and Modern Society, London: Sage Publication Ltd.

10. O'Sullivan (1999) Decession Making in Social Work. MacMillan Press Ltd Houndmills. London.

11. Parrillo, Vincent N. 2002. Contemporary Social Problem, Fifth Edition. Allyn and Bacon Boston USA.

12. Phlillips, Norma Kolko, et. al. 2002 Urban Social Work, Introduction to Policy and Practice in the Cities, Allyn and Bacon, Boston USA.

13. Sheppard, Michael. 2006. Social Work and Social Exclusion. The Idea of Practice. Great Britain, Padstow, Cornwall. P. 59-79

14. Suharto, Edi, 1997. Pembangunan, Kebijakan Sosial dan Pekerjaan Sosial, Percikan Pemikiran, LSP Bandung.

15...................... 2005. Membangun

Rakyat Memberdayakan Rakyat. Refika

16. ...................... 2006 Peta dan Dinamika Welfare State di Beberapa Negara. Makalah. Disampaikan dalam Seminar "Mengkaji Ulang Relevansi Welfare State dan Terobosan melalui Desentralisasi-Otonomi di Indonesia", Institute for Research and Empowerment (IRE) Yogyakarta. 25 Juli 2006.

17. ...................... 2009. Pekerjaan Sosial di Dunia Industri. Alfabeta Bandung.

18. ....................... 2011. Kebijakan Sosial sebagai Kebijakan Publik. Alfabeta. Bandung.

19. United Nation Report (1968: 40-41)

20. Wickenden, Elizabeth. 1965. Social Welfare in a Changing World. Washington DC. University Press. 
Bandung, 1 Nopemberf 2013

Purwowibowo*)

*)Dosen di Jurusan Ilmu

Kesejahteraan Sosial Fakultas Ilmu Sosial dan

Ilmu Politik Universitas Jember, sekarang

sedang melanjutkan Studi di Program

Pascasarjana S-3 Program Studi Ilmu

Kesejahteraan Sosial Universitas Padjadjaran

Bandung 